\title{
Pengaruh Kecerdasan Intelektual, Kecerdasan Spiritual dan Kecerdasan Emosional terhadap Persepsi Etis Mahasiswa Akuntansi
}

\author{
Chandra Wijaya ${ }^{1}$ \\ Maria Mediatrix Ratna Sari ${ }^{2}$ \\ ${ }^{1,2}$ Fakultas Ekonomi dan Bisnis Universitas Udayana (Unud), Bali, Indonesia \\ e-mail: chandra170295@yahoo.com
}

\begin{abstract}
ABSTRAK
Penelitian ini bertujuan untuk meneliti pengaruh kecerdasan intelektual, kecerdasan spiritual dan kecerdasan emosional terhadap persepsi etis mahasiswa akuntansi. Objek penelitian adalah mahasiswa aktif program studi akuntansi semester 7 ke atas Fakultas Ekonomi dan Bisnis Universitas Udayana. Sampel dalam penelitian ini berjumlah 80 orang. Pengumpulan data menggunakan metode kuesioner. Metode analisis yang digunakan dalam penelitian ini adalah analisis regresi linier berganda. Berdasarkan hasil analisis penelitian, dapat dikatakan Kecerdasan Intelektual memiliki pengaruh positif terhadap Persepsi Etis Mahasiswa Akuntansi, Kecerdasan Spiritual memiliki pengaruh positif terhadap Persepsi Etis Mahasiswa Akuntansi, dan Kecerdasan Emosional memiliki pengaruh positif terhadap Persepsi Etis Mahasiswa Akuntansi.

Kata kunci : Kecerdasan intelektual, kecerdasan spiritual, kecerdasan emosional, mahasiswa, persepsi etis.
\end{abstract}

\begin{abstract}
This study aims to examine the effect of intellectual intelligence, spiritual intelligence and emotional intelligence on the ethical perceptions of accounting students. The object of research is active students of the 7th semester accounting study program at the Faculty of Economics and Business, Udayana University. The sample in this study amounted to 80 people. Data collection using the questionnaire method. The analytical method used in this study is multiple linear regression analysis. Based on the results of the research analysis, it can be said that Intellectual Intelligence has a positive influence on the Ethical Perceptions of Accounting Students, Spiritual Intelligence has a positive influence on Ethical Perceptions of Accounting Students, and Emotional Intelligence has a positive influence on Ethical Perceptions of Accounting Students.

Keywords : Intellectual intelligence, spiritual intelligence, emotional intelligence, students, ethical perception.
\end{abstract}

\section{PENDAHULUAN}

Pentingnya peran seorang akuntan bagi masyarakat disebabkan oleh berbagai informasi yang mereka sediakan yang berarti bersumber dari akuntan yang disampaikan berdasarkan pendapatnya atas laporan keuangan perusahaan diperlukan oleh pihak-pihak yang berkepentingan seperti investor, manajer dan 
pihak lainnya dalam mengambil keputusan. Kegitan akuntansi berhubungan erat dengan etika, karena kegiatan ini membutuhkan pertimbangan seorang akuntan namun pada kenyataannya tidak mudah bagi seorang akuntan untuk mempertimbangkan pengambilan keputusan. Kepercayaan masyarakat akan berkurang seiring dengan terjadinya pelanggaran etika yang dilakukan oleh seorang akuntan. Dengan demikian, dibutuhkan kesadaran etika seorang akuntan dalam proses pengambilan keputusan (Wati \& Sudibyo, 2016).

Pada saat ini etika menjadi isu yang penting, banyak kemunculan kasus terkait dengan persoalan etika. Salah satu contohnya adalah skandal yang melibatkan perusahaan besar di dunia yaitu Enron, KAP Arthur Anderson dan Worldcom. Skandal serupa yang terjadi di Indonesia dapat dilihat pada kasus mega proyek e-KTP yang merugikan negara hingga Rp. 2,3 Triliun melibatkan 5 perusahaan pemenang tender. Kasus markup harga bahan baku pembuatan e-KTP ini selain dari pihak manajemen yang menginginkan keuntungan berlipat juga disebabkan oleh rendahnya kompetensi dan profesional kerja akuntan perusahaan yang turut terlibat melakukan pencatatan harga bahan baku yang telah di markup (news.detik.com).

Kasus lain mengenai pelanggaran etika adalah penangkapan anggota Komisi Pemilihan Umum (KPU), Mulyana W Kusuma terkait dugaan melakukan penyuapan kepada anggota tim auditor BPK yaitu Salman Khairiansyah. Namun Salman Khairiansyah mengaku bekerjasama dengan KPK untuk memerangkap upaya penyuapan saudara Mulyana menggunakan alat perekam gambar (Nasution, 2005, https://news.detik.com). Berdasarkan sudut pandang etika 
profesi, auditor BPK tidak menerapkan prosedur pemeriksaan sebagaimana yang telah diatur dalam profesi akuntan. Auditor telah menggunakan cara yang tidak etis, yaitu dengan jebakan meskipun hal tersebut dilakukan dengan alasan untuk mengungkap indikasi terjadinya korupsi di tubuh KPU.

Seorang akuntan diharapkan memiliki pengetahuan, pemahaman, serta mampu menerapkan nilai moral dan etika dalam melaksanakan tugasnya sehingga tidak terjadi kasus maupun pelanggaraan etika dalam profesi akuntansi. Hasil analisis terhadap sikap etis pada profesi akuntansi menunjukkan bahwa akuntan memiliki kesempatan untuk bertindak yang tidak etis dalam profesi mereka. Dengan demikian seorang akuntan harus memiliki etika agar dapat menentukan status serta kredibilitas profesi akuntansi (Widyaningrum, 2014).

Dalam dunia profesi akuntansi terdapat banyak skandal etis yang terjadi, hal tersebut menunjukkan bahwa terjadi krisis perilaku etis yang melanda dunia etika bisnis, oleh karena itu diperlukan penelitian tentang persepsi etis terhadap isu etika yang terjadi saat ini. Persepsi merupakan sebuah proses dengan melibatkan hal-hal yang diketahui sebelumnya saat memperoleh serta menginterpretasikan kombinasi faktor dunia luar dalam bentuk visual dan dari dalam diri sendiri berupa hal-hal yang diketahui sebelumnya. Persepsi dipelajari secara luas dan tidak ada seorang pun yang punya pengetahuan dan pengalaman yang sama, maka jika seseorang dihadapkan oleh hal yang sama seperti situasi atau rangsangan akan menghasilkan perilaku dan reaksi yang berbeda.

Setiap orang mempunyai perbedaan saat menginterpretasikan objek yang diterima lewat panca indera yang mereka miliki. Sebuah perbedaan akan terjadi 
disebabkan oleh dua faktor berupa faktor dunia luar atau stimulusa visual dan faktor kognitif. Tekanan waktu, sikap orang lain, dan faktor-faktor situasi lainnya merupakan faktor eksternal atau dunia luar yang mempengaruhi keefektifan persepsi (Christin, 2007). Sedangkan faktor kognitif yang dapat mempengaruhi persepsi individu terdiri dari tiga aspek dasar yang dimiliki oleh individu itu sendiri yaitu kecerdasan intelektual (IQ), kecerdasan spiritual (SQ), dan kecerdasan emosional (EQ).

Kesadaran, ingatan, pikiran dan bahasa banyak mempengaruhi persepsi. Oleh karena itu, persepsi tidak mencerminkan realitas (Novius, 2008). Untuk mencapai sebuah keberhasilan yang diingankan faktor internal yang sangat berpengaruh antara lain adalah kecerdasan emosional, kecerdasan spiritual serta kecerdasan intelektual. Berdasarkan pernyataan-pernyataan tersebut, peneliti ingin meneliti lebih dalam mengenai faktor-faktor kognitif tersebut.

Kecerdasan intelektual (IQ) adalah sebuah istilah untuk pengukuran tingkat kecerdasan individu.. IQ merupakan istilah untuk sebuah kecerdasan akal seseorang yang berbentuk kecerdasan menulis, membaca, dan menghitung. Seseorang yang memiliki tingkat IQ yang tinggi cenderung berperilaku lebih etis karena dia mampu menghadapi sesuatu dengan kecakapan yang dimilikinya.

Kecerdasan spiritual (SQ) hubungannya adalah dengan agama atau kepercayaan seseorang. Seseorang dengan tingkat spiritual yang tinggi akan lebih cenderung berpikir dan bertindak lebih etis sesuai dengan berbagai ajaran agama yang mengajarkan kebaikan dan tidak merugikan orang lain. 
Kecerdasan emosional (EQ) merupakan kemampuan seseorang dalam mengetahui perasaannya serta perasaan orang lain kemudian perasaan tersebut digunakan untuk menuntun pikiran dan perilaku seseorang. Dengan tingkat kecerdasan emosional yang tinggi, seseorang akan cenderung untuk bertindak lebih etis jika dihadapkan dengan suatu masalah karena dia tidak hanya mementingkan perasaan diri sendiri namun juga perasaan orang lain.

Hasil penelitian Wardana \& Mimba (2016) menunjukkan bahwa tingkat pendidikan, kebudayaan intranasional, dan jenis kelamin berpengaruh secara signifikan terhadap persepsi etis. Berdasarkan hasil penelitian tersebut ditemukan juga bahwa pendidikan yang lebih tinggi akan memiliki kecenderungan yang lebih tinggi pula terhadap perilaku etis. Pendidikan bertujuan bukan hanya untuk mengembangkan kecerdasan intelektual, kecerdasan emosional serta kecerdasan spiritual juga perlu dikembangkan agar peserta didik menjadi insan yang berilmu dengan memiliki sikap etis (Wardana \& Mimba, 2016).

Banyak fenomena yang terjadi pada kehidupan mahasiswa diantaranya mengenai pelanggaran etika yang dilakukan baik secara sadar maupun tidak sadar. Mahasiswa saat ini cenderung berorientasi pada hasil dan memandang etika sebagai hal yang kurang penting. Hal ini menjadikan persepsi etis mahasiswa menjadi rendah. Rendahnya tingkat persepsi etis mahasiswa akan membuat sebuah anggapan terhadap tindakan etis yang dilakukan menjadi hal yang dianggap normal serta dapat menjadi kebiasaan di kalangan mahasiswa tersebut (Pemayun, 2018). Penelitian mengenai etika yang dilakukan Wardana \& Mimba (2016) menyatakan bahwa mahasiswa akuntansi mempunyai tingkat kesadaran 
yang lebih rendah daripada mahasiswa non akuntansi. Hal ini memperkuat alasan peneliti untuk melakukan penelitian di kalangan mahasiswa khususnya mahasiswa akuntansi.

Hasil penelitian sebelumnya oleh Agustini \& Herawati (2010) menunjukkan bahwa kecerdasan emosional, kecerdasan intelektual dan kecerdasan spiritual berpengaruh positif terhadap perilaku etis mahasiswa. Hal ini bertentangan dengan hasil penelitian Aprilianto (2017) bahwa kecerdasan emosi dan kecerdasan spiritual tidak berpengaruh secara signifikan terhadap tingkat pemhaman akuntansi pada mahasiswa akuntansi. Oleh karena adanya inkonsistensi hasil penelitian sebelumnya maka peneliti ingin menguji kembali faktor kognitif yang mempengaruhi persepsi etis mahasiswa.

Berdasarkan latar belakang yang telah dijabarkan, maka rumusan masalah yang diangkat pada penelitian ini adalah. Bagaimana pengaruh kecerdasan intelektual terhadap persepsi etis mahasiswa akuntansi. Bagaimana pengaruh kecerdasan spiritual terhadap persepsi etis mahasiswa akuntansi. Bagaimana pengaruh kecerdasan emosional terhadap persepsi etis mahasiswa akuntansi.

Manfaat teoritis dari penelitian ini adalah untuk memberikan bukti secara empiris yang memberikan dukungan terhadap teori perkembangan moral kognitif dan untuk memberikan bukti secara empiris mengenai pengaruh Kecerdasan Intelektual, Kecerdasan Emosional dan Kecerdasan Spiritual terhadap Persepsi Etis Mahasiswa Akuntansi. Hasil penilitian ini agar dapat menjadi acuan atau sebagai sumber informasi serta referensi bagi peneliti-peneliti lain, terutama dalam penelitian mengenai persepsi etis mahasiswa akuntansi. Serta dapat 
memberikan masukan bagi dunia akademisi khususnya dalam bidang pendidikan akuntansi pada perguruan tinggi dalam mendidik dan mendiskusikan mengenai pentingnya kecerdasan intelektual, kecerdasan emosional dan kecerdasan spiritual dalam pola pendidikan karena ketiga hal tersebut dapat mempengaruhi persepsi etis mahasiswa akuntansi.

Grand theory yang mendasari penelitian ini adalah teori perkembangan moral kognitif Kohlberg. Kohlberg (1987) dikenal sebagai tokoh fenomenal yang mengenalkan psikologi moral Kognitif. Berdasarkan teori ini dasar dari perilaku etis adalah penalaran moral. Penalaran moral yang dimaksud adalah cara menilai sebuah makna, hal-hal mengenai sosial, serta hal terkait kewajiban seseorang dalam melakukan sebuah tindakan. Menurut Kohlberg pertimbangan moral adalah aktivitas kognitif yang terjadi pada tahap mental. Pertimbangan moral (moral judgement) adalah semacam penghakiman normatif. Normatif merupakan keyakinan individu bahwa sesuatu itu baik atau buruk, benar atau salah, seharusnya atau tidak seharusnya.

Kata Etika berasal dari kata Yunani "ethos" yang berarti adat istiadat atau kebiasaan. Bertens (2000) mendefinisikan etika sebagai cabang filsafat yang mempelajari baik buruknya perilaku manusia. Hal-hal yang meliputi etika adalah sebuah proses seseorang dalam menentukan sesuatu yang dianggap perlu untuk dilakukan pada situasi tertentu berdasarkan kombinasi atas hasil dari pengalaman dan pembelajaran yang diperoleh. Arshinta dkk., (2017) mengatakan bahwa tujuan mengetahui etika bukan hanya sekedar supaya paham tentang berbagai pemikiran-pemikiran maupun teorinya, melainkan untuk mempengaruhi dan 
mendorong kehendak individu supaya mengarah kepada hal-hal yang berfaedah dan berguna bagi sesama manusia.

Menurut Risela (2016) persepsi adalah pengalaman tentang objek, peristiwa atau hubungan-hubungan yang diperoleh dengan menyimpulkan informasi dan menafsirkan pesan. Pesan dapat dikatakan sebagai pemberian makna pada stimuli indrawi (sensory stimuli). Lebih jelasnya, persepsi merupakan tindakan mengenali, menyusun serta mengartikan sebuah informasi sensorik untuk mendapatkan gambaran dan memahami lingkungan sekitarnya. Persepsi juga diartikan sebagai cara seseorang menyeleksi, mengatur, dan menginterpretasikan informasi yang didapat guna memberikan gambaran secara menyeluruh (Kotler, 2014).

Persepsi etis adalah tanggapan dan penilaian yang muncul dari pemikiran kritis mengenai apa yang harus dan tidak harus dilakukan seseorang dalam situasi tertentu. Persepsi etis atas suatu hal adalah persepsi individu mengenai etis atau tidak etisnya suatu hal (Risela, 2016). Persepsi Etis Mahasiswa Akuntansi adalah pandangan seorang mahasiswa akuntansi terkait dengan perilaku etis atau tidak etis seorang akuntan dilihat dari pengalaman dan pembelajaran yang didapat selama menjadi mahasiswa sebagai seorang calon akuntan. Skandal etis yang biasanya terjadi yaitu konflik kepentingan, penghindaran pajak, pembelian yang dilakukan orang dalam, kerahasiaan professional dan pembayaran kembali (Mardawati, 2014).

Kecerdasan Intelektual (IQ) merupakan istilah untuk sebuah kecerdasan formal mengenai hal-hal yang menyangkut cara seseorang dalam merubah bentuk 
atau menggunakan aturan formal yang menyerupai aturan mengenai tata bahasa atau aritmatika (Zohar \& Marshall, 2005). Seseorang yang mampu menguasai sebuah konsep aturan formal dengan mudah dan dapat memanipulasinya dapat dikatakan sebagai seseorang yang memiliki kecerdasan intelektual. Skor IQ mencerminkan tingkat atas kemampuan tertentu yang dimiliki seseorang dan sebagian besar terwariskan berupa kemampuan mengenai tata ruang, angkaangka, serta tata bahasa (Zohar \& Marshall, 2005).

Kecerdasan spiritual (SQ) merupakan istilah untuk sebuah kecerdaasan yang dimiliki seseorang dalam menangani masalah-masalah tentang makna atau nilai berupa kecerdasan dalam bertindak pada konteks yang lebih luas dalam menilai tindakan atau keputusan yang dipilih seseorang dalam menjalani kehidupannya lebih berarti dibandingkan dengan orang lain (Zohar \& Marshall, 2005). SQ merupakan kecerdasan yang memiliki peran sebagai landasan yang dibutuhkan dalam memfungsikan EQ dan IQ secara efektif (Misbach, 2008). Kecerdasan spiritual dalam diri seseorang dapat memicu sebuah kesadaran yang tinggi serta kecakapan dalam menjalani kehidupannya sehari-hari dan dianggap sebagai sebuah berkah yang suci dengan menggunakan sumber spiritual dalam memecahkan masalah-masalah yang dihadapai dalam kaitannya dengan budi pekerti luhur (Emmons, 2000).

Kecerdasan seseorang secaara umum hanya dinilai berdasarkan akal sehatnya. Tetapi keberhasilan hidup tidak hanya terukur dari sebuah keberhasilan akademik melainkan terdapat berbagai faktor lainnya. Kecerdasan Emosional atau Emotional (Quotient (EQ) merupakan seperangkat kecapakapan yang dimiliki 
seseorang diluar dati kecerdasan intelektual yaitu talenta, hubungan antara sesama manusia, tingkat emosional yang matang, cara mengendalikan diri yang baik, serta hal lain yang serupa. EQ didefenisikan sebagai sekumpulan bagian dari kecerdasan sosial dengan unsur kemampuan memahami perasaan sosial yang melibatkan kemampuan terhadap orang lain serta menggunakan informasi yang didapat untuk dijadikan pembimbing tindakan dan pikiran mereka. Kecerdasan emosional mengacu pada kemampuan seseorang dalam mengenali perasaannya sendiri serta perasaan orang lain, mampu memotivasi diri sendiri serta dapat mengendalikan emosi dengan baik serta dalam hubungan dengan orang lain (Goleman, 2005).

Teori perkembangan moral Kohlberg menjelaskan bahwa perkembangan moral berkorelasi dengan kecerdasan individu. Salah satu kecerdasan manusia adalah kecerdasan intelektual. Menurut Risela (2016) kemampuan yang dibutuhkan untuk melakukan segala aktivitas mental dapat dikatakan sebagai Kecerdasan Intelektual (IQ). Semakin tinggi IQ yang dimiliki maka kemampuan dalam menghadapi masalah yang berhubungan dengan kemampuan tata ruang, angka-angka, dan tata bahasa juga akan semakin tinggi. Dari pendapat tersebut, diharapkan bahwa mahasiswa yang memiliki IQ yang tinggi akan lebih mudah untuk menyerap ilmu yang diberikan, khususnya ilmu yang berkaitan dengan etika sehingga hal tersebut dapat mempengaruhi persepsi etis mahasiswa akuntansi.

Berdasarkan penelitian yang dilakukan oleh Risela (2016) kecerdasan intelektual berpengaruh positif terhadap persepsi etis mahasiswa Universitas 
Negeri Yogyakarta. Arshinta dkk., (2017) dalam penelitiannya juga menemukan bahwa kecerdasan intelektual berpengaruh positif terhadap persepsi etika mahasiswa akuntansi. Berdasarkan pemahaman di atas, maka dapat dirumuskan hipotesis penelitian sebagai berikut:

$\mathrm{H}_{1}$ : Kecerdasan Intelektual berpengaruh positif terhadap Persepsi Etis Mahasiswa Akuntansi Fakultas Ekonomi dan Bisnis Universitas Udayana.

Teori perkembangan moral Kohlberg menjelaskan bahwa perkembangan moral berkorelasi dengan kecerdasan individu. Salah satu kecerdasan manusia adalah kecerdasan spiritual. Kecerdasan spiritual (SQ) adalah istilah untuk sebuah kecerdasan yang dimiliki seseorang dalam menghadapi masalah-masalah mengenai sebuah makna atau nilai, kecerdasan dalam berperilaku pada konteks yang lebih luas dengan mampu menilai sebuah tindakan atau jalan hidup yang dipilih lebih bermakna bila dibandingkan dengan orang lain (Zohar \& Marshall, 2005).

Mahasiswa yang mempunyai kecerdasan spiritual yang tinggi cenderung memiliki dorongan untuk mempunyai pola pikir yang kritis dan terbuka, memiliki rasa kepercaya yang tinggi serta keinginan untuk mengetahui sesuatu yang tinggi pula dalam konteks positif. Memiliki sifat torelansi dan memahami pentingnya sebuah proses yang perlu dilalui dengan berlandaskan iman dan kepercayaan nya terhadap Tuhan. Mahasiswa dengan kecerdaasan spiritual yang rendah akan cenderung berperilaku sebaliknya, sehingga dapat dikatakan bahwa kecerdasan spiritual dapat mempengaruhi hal-hal mengenai pandangan atas baik buruknya sebuah hal tertentu. 
Arshinta dkk., (2017) dalam penelitiannya menemukan bahwa kecerdasan spiritual berpengaruh positif terhadap persepsi etika mahasiswa akuntansi. Berdasarkan pemahaman di atas, maka dapat dirumuskan hipotesis penelitian sebagai berikut:

$\mathrm{H}_{2}$ : Kecerdasan Spiritual berpengaruh positif terhadap Persepsi Etis Mahasiswa Akuntansi Fakultas Ekonomi dan Bisnis Universitas Udayana.

Teori perkembangan moral Kohlberg menjelaskan bahwa perkembangan moral berkorelasi dengan kecerdasan individu. Salah satu kecerdasan manusia adalah kecerdasan emosional. Kecerdasan emosional merupakan istilah untuk sebuah kecerdasan yang dimiliki seseorang berupa kemampuan dalam mengetahui perasaan dalam diri dan orang lain, memiliki motivasi dalam diri, dan dapat mengendalikan emosi tersebut dengan baik sehingga dapat menjaga hubungan baiknya dengan orang lain dan berdamai terhadap diri sendiri (Goleman, 2005). Kecerdasan emosional tinggi dalam diri mahasiswa akan memicu keberhasilan di dalam kehidupannya karena mempunyai motivasi yang tinggi dalam hidup untuk selalu berpikir jernih dalam melakukan tindakan dan berpendapat, sedangkan mahasiswa dengan kecerdasan emosional yang rendah akan mengalami hal yang sebaliknya. Hal ini dapat mempengaruhi pola pikir mahasiswa dalam membuat sebuah persepsi yang baik.

Berdasarkan penelitian yang dilakukan oleh Risela (2016) kecerdasan emosional berpengaruh positif terhadap persepsi etis mahasiswa Universitas Negeri Yogyakarta. Arshinta dkk., (2017) dalam penelitiannya juga menemukan bahwa kecerdasan emosional berpengaruh positif terhadap persepsi etika mahasiswa akuntansi. Berdasarkan pemahaman di atas, maka dapat dirumuskan 
hipotesis penelitian sebagai berikut:

$\mathrm{H}_{3}$ : Kecerdasan Emosional berpengaruh positif terhadap Persepsi Etis Mahasiswa Akuntansi Fakultas Ekonomi dan Bisnis Universitas Udayana

\section{METODE PENELITIAN}

Penelitian ini menggunakan pendekatan kuantitatif yang berbentuk asosiatif dengan tipe kualitas. Penelitian ini bertujuan untuk mengetahui pengaruh kecerdasan intelektual, kecerdasan spiritual, dan kecerdasan emosional pada persepsi etis mahasiswa akuntansi. Lokasi Penelitian ini dilakukan pada Fakultas Ekonomi dan Bisnis Universitas Udayana yang beralamat di Jl. Raya Kampus Unud No. 2013, Jimbaran dan Jl. P.B. Sudirman, Denpasar.

Objek dalam penelitian ini berupa persepsi etis mahasiswa semester tujuh ke atas, program studi akuntansi Fakultas Ekonomi dan Bisnis Univesitas Udayana dalam pengaruh Kecerdasan Intelektual, Kecerdasan Spiritual dan Kecerdasan Emosional terhadap Persepsi Etis Mahasiswa Akuntansi. Populasi dalam penelitian ini adalah seluruh mahasiswa aktif akuntansi Fakultas Ekonomi dan Bisnis Universitas Udayana semester tujuh ke atas yang berjumlah 406 orang, dengan rincian angkatan 2013 berjumlah 43 orang, angkatan 2014 berjumlah 69 orang, dan angkatan 2015 berjumlah 294. Probability sampling merupakan teknik pengambilan sampel yang memberikan peluang yang sama bagi setiap anggota populasi untuk dipilih sebagai sampel. Teknik ini dipilih dengan menggunakan teknik random sederhana, yaitu secara acak tanpa memperhatikan strata yang ada dalam populasi tersebut. Rumus perhitungan jumlah sample berdasarkan Teori Slovin, Pemayun (2018) adalah sebagai berikut : 


$$
\mathrm{n}=\frac{\mathrm{N}}{1+\mathrm{N}(\mathrm{e})^{2}}
$$

Keterangan:

$$
\begin{array}{ll}
\mathrm{n} & =\text { ukuran sampel } \\
\mathrm{N} & =\text { ukuran populasi } \\
\mathrm{e} & =\text { ukuran ketelitian }(10 \%)
\end{array}
$$

Sehingga:

$$
\begin{aligned}
& \mathrm{n}=\frac{406}{1+406(0,1)^{2}} \\
& \mathrm{n}=80 \text { (dibulatkan). }
\end{aligned}
$$

Berdasarkan perhitugan di atas maka besarnya sampel dari populasi adalah 80 mahasiswa.

Metode pengumpulan data dalam penelitian ini menggunakan teknik kuesioner. Kuesioner yang digunakan berisikan kasus dan pernyataan-pernyataan tentang masalah yang ada kaitannya dengan objek pada penelitian ini. Pemilihan responden dilakukan dengan teknik probability sampling dengan metode random sederhana, yaitu memberikan peluang yang sama bagi setiap anggota populasi untuk dipilih sebagai responden secara acak tanpa memperhatikan strata yang ada dalam populasi tersebut. Data yang diperoleh merupakan data primer berupa hasil kuesioner yang dijawab dan didapat langsung dari responden yang merupakan sumber asli tanpa melalui perantara berupa pendapat orang secara peribadi atau kelompok serta hasil observasi terhadap kejadian atau kegiatan. Instrumen yang digunakan dalam penelitian ini diukur menggunakan skala Likert.

Penelitian ini menggunakan teknik analisis data berupa analisis regresi 
linier berganda. Sebelum melakukan analisis regresi, terlebih dahulu wajib dilakukan uji asumsi klasik. Pengujian ini meliputi uji normalitas, uji heterokedastisitas dan uji multikolinearitas. Teknik analisis data yang digunakan dalam penelitian ini adalah teknik analisis regresi linier berganda. Berikut adalah model regresi dalam penelitian ini :

$Y=\alpha+\beta_{1} X_{1}+\beta_{2} X_{2}+\beta_{3} X_{3}+e$

Keterangan:

Y : Persepsi Etis

$\alpha \quad$ : Konstanta

B $\quad$ : Koefisien Regresi

$\mathrm{X}_{1} \quad$ : Kecerdasan Intelektual (IQ)

$\mathrm{X}_{2} \quad$ : Kecerdasan Spiritual (SQ)

$\mathrm{X}_{3} \quad$ : Kecerdasan Emosional (EQ)

e : error

Selanjutnya dilakukan analisis hipotesis berupa uji koefisien determinasi $\left(\mathrm{R}^{2}\right)$, uji kelayakan model (Uji F) dan uji hipotesis (Uji t).

\section{HASIL DAN PEMBAHASAN}

Hasil rekapitulasi uji validitas dalam penelitian ini disajikan dalam Tabel 1 berikut:

Tabel 1. Rekapitulasi Hasil Uji Validitas dan Uji Reliabilitas Instrumen Penelitian

\begin{tabular}{ccccccc}
\hline Variabel & Indikator & $\begin{array}{c}\text { Koefisien } \\
\text { Korelasi }\end{array}$ & $\begin{array}{c}\text { Sig. }(2- \\
\text { tailed })\end{array}$ & $\begin{array}{c}\text { Ketera } \\
\text { ngan }\end{array}$ & $\begin{array}{c}\text { Cronbach's } \\
\text { Alpha }\end{array}$ & $\begin{array}{c}\text { Ketera } \\
\text { ngan }\end{array}$ \\
\hline & $\mathrm{X}_{1.1}$ & 0,766 & 0,000 & Valid & & \\
& $\mathrm{X}_{1.2}$ & 0,773 & 0,000 & Valid & & \\
Kecerdasan & $\mathrm{X}_{1.3}$ & 0,831 & 0,000 & Valid & & \\
intelektual & $\mathrm{X}_{1.4}$ & 0,737 & 0,000 & Valid & & Reliabel \\
$\left(\mathrm{X}_{1}\right)$ & $\mathrm{X}_{1.5}$ & 0,771 & 0,000 & Valid & 0,775 & \\
& $\mathrm{X}_{1.6}$ & 0,666 & 0,000 & Valid & & \\
& $\mathrm{X}_{1.7}$ & 0,597 & 0,000 & Valid & &
\end{tabular}


Chandra Wijaya dan Maria Madiatrix Ratna Sari. Pengaruh ...

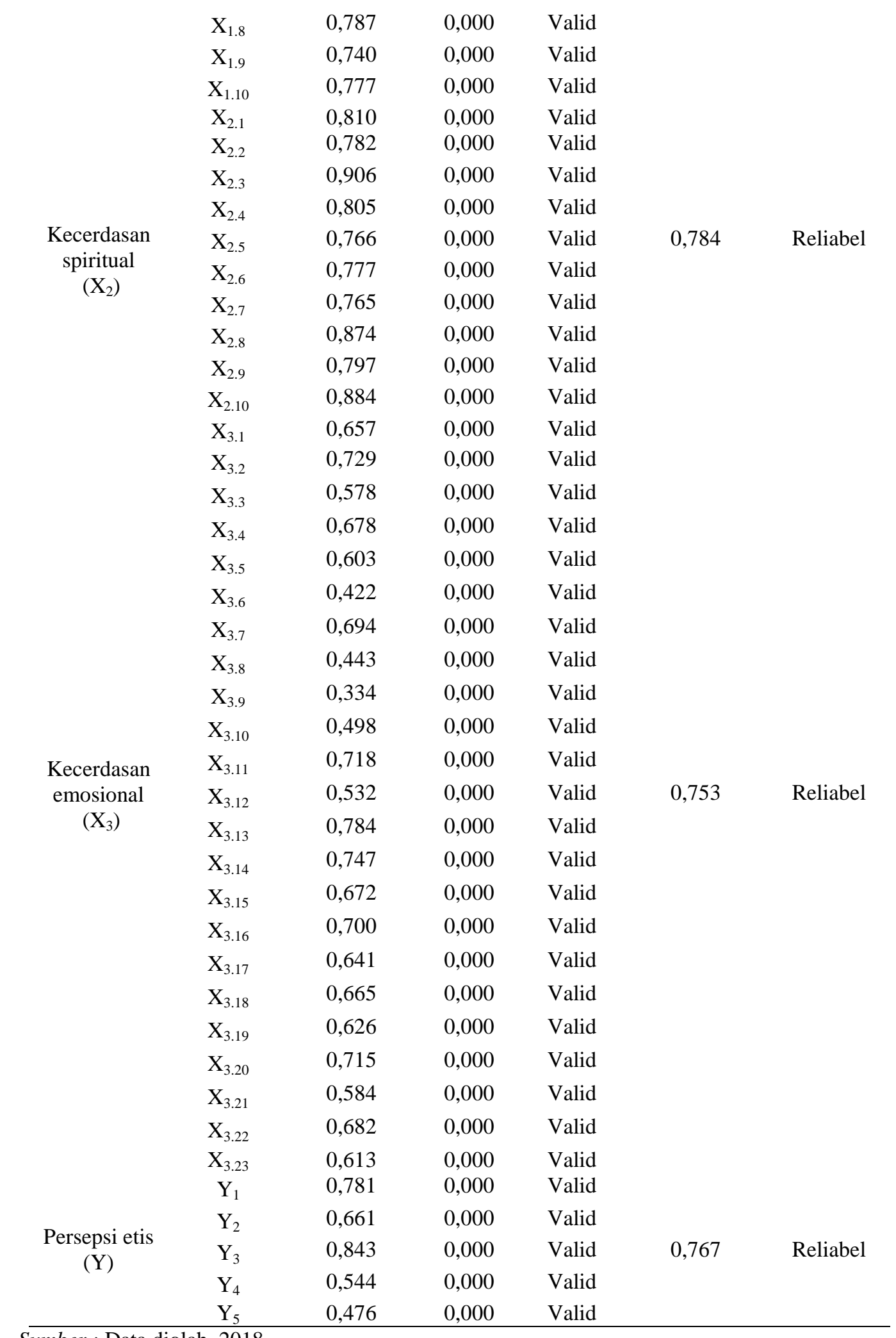

Sumber : Data diolah, 2018

Berdasarkan tabel 1 dapat dilihat bahwa indikator penelitian yang 
digunakan untuk mengukur variabel kecerdasan intelektual, kecerdasan spiritual, kecerdasan emosional, dan persepsi etis mempunyaii nilai koefisien korelasi dengan skor total seluruh butir pernyataan lebih besar dari 0,30 dengan signifikansi kurang dari 0,05. Oleh karena itu, dapat dikatakan bahwa butir-butir pernyataan dalam instrumen penelitian ini valid dan layak digunakan sebagai instrument penelitian. Berdasalkan hasil uji reliabilitas pada Tabel 1 dapat dilihat bahwa variabel penelitian mempunyai nilai koefisien Cronbach's Alpha lebih dari 0,60. Dengan demikian kesimpulan yang dapat diambil adalah seluruh variabel telah memenuhi syarat reliabilitas dan dapat digunakan dalam penelitian ini.

Tabel 2.

Statistik Deskriptif

\begin{tabular}{crrrrr}
\hline Variabel & $N$ & \multicolumn{1}{c}{ Minimum } & Maximum & \multicolumn{1}{c}{ Mean } & Std. Deviation \\
\hline $\mathrm{X}_{1}$ & 80 & 30.00 & 50.00 & 40.7250 & 5.41908 \\
$\mathrm{X}_{2}$ & 80 & 30.00 & 50.00 & 41.9750 & 6.34449 \\
$\mathrm{X}_{3}$ & 80 & 71.00 & 115.00 & 98.2500 & 9.14233 \\
$\mathrm{Y}$ & 80 & 5.00 & 15.00 & 7.9875 & 2.24733 \\
Valid N (listwise) & 80 & & & &
\end{tabular}

Sumber : Data diolah, 2018

Berdasarkan statistik deskriptif pada Tabel 2 hasil kuesioner yang diperoleh dari sampel yang berjumlah 80 orang dengan menggunakan skala Likert 1-5, maka diketahui: variabel kecerdasan intelektual dengan nilai minimum 30, nilai maximum 50, nilai rata-rata 40,725, dengan standar deviasi 5,41908; variabel kecerdasan spiritual dengan nilai minimum 30, nilai maximum 50, nilai rata-rata 41,975, dengan standar deviasi 6,34449; variabel kecerdasan emosional dengan nilai minimum 71 , nilai maximum 115 , nilai rata-rata 98,25 , dengan standar deviasi 9,14233; dan variabel persepsi etis memiliki nilai minimum 5, nilai maximum 15, nilai rata-rata 7,9875, dengan standar deviasi 2,24733. 
Tabel 3.

Hasil Uji Asumsi Klasik

\begin{tabular}{|c|c|c|c|c|}
\hline \multirow{2}{*}{ Parameter Yang Diuji } & \multirow{2}{*}{$\begin{array}{c}\text { Uji Normalitas } \\
\text { Asymp. Sig. } \\
\text { (2-tailed) }\end{array}$} & \multirow{2}{*}{$\begin{array}{c}\text { Uji } \\
\begin{array}{c}\text { Heteroskedasti } \\
\text { sitas }\end{array} \\
\text { Sig. }\end{array}$} & \multicolumn{2}{|c|}{ Uji Multikolinearitas } \\
\hline & & & Tolerance & VIF \\
\hline $\begin{array}{l}\text { Unstandarized } \\
\text { Residual }\end{array}$ & 0,998 & & & \\
\hline $\begin{array}{l}\text { Kecerdasan intelektual } \\
\text { (X1) }\end{array}$ & & 0,228 & 0,624 & 1,603 \\
\hline $\begin{array}{l}\text { Kecerdasan spiritual } \\
\text { (X2) }\end{array}$ & & 0,115 & 0,864 & 1,158 \\
\hline $\begin{array}{l}\text { Kecerdasan emosional } \\
\text { (X3) }\end{array}$ & & 0,228 & 0,651 & 1,536 \\
\hline
\end{tabular}

Hasil uji normalitas pada Tabel 3 menunjukkan nilai Asymp. Sig (2-tailed) 0,1998 lebih besar dari level of significant, yaitu 5 persen $(0,05)$ dengan demikian data yang diuji menyebar normal atau berdistribusi normal. Nilai tolerance persamaan regresi linear berganda pada masing-masing variabel yaitu diatas $10 \%$ $(0,10)$ dan nilai VIF dibawah 10. Dengan demikian dapat dikatakan bahwa tidak terjadi multikolinearitas terhadap model regresi yang digunakan. Nilai sigifikansi dari variabel kecerdasan intelektual yaitu 0,228, kecerdasan spiritual adalah 0,115, dan kecerdasan emosional adalah 0,228. Nilai tersebut lebih besar dari 0,05 sehingga dapat dikatakan bahwa variabel bebas tidak memiliki pengaruh terhadap absolute residual. Sehingga dapat dinyatakan bahwa tidak terdapat gejala heteroskedastisitas pada model penelitian ini.

Penggunaan analisis regresi linier berganda dalam penelitian ini adalah untuk menganalisis pengaruh kecerdasan intelektual $\left(\mathrm{X}_{1}\right)$, kecerdasan spiritual 
$\left(\mathrm{X}_{2}\right)$, dan kecerdasan emosional $\left(\mathrm{X}_{3}\right)$ terhadap persepsi etis $(\mathrm{Y})$. Tabel 4 menunjukkan hasil analisis regresi linier berganda sebagai berikut :

Tabel 4.

Hasil Uji Regresi Linear Berganda

\begin{tabular}{|c|c|c|c|c|c|}
\hline \multirow[t]{2}{*}{ Model } & \multicolumn{2}{|c|}{$\begin{array}{l}\text { Unstandardized } \\
\text { Coefficients }\end{array}$} & \multirow{2}{*}{$\begin{array}{l}\text { Standardized } \\
\text { Coefficients } \\
\text { Beta }\end{array}$} & \multirow[t]{2}{*}{$\mathrm{T}$} & \multirow[t]{2}{*}{ Sig. } \\
\hline & $\mathrm{B}$ & Std. Error & & & \\
\hline Constant) & $-8,777$ & 2,134 & & $-4,112$ & 0,000 \\
\hline Kecerdasan Intelektual & 0,128 & 0,044 & 0,308 & 2,921 & 0,005 \\
\hline Kecerdasan Spiritual & 0,065 & 0,032 & 0,185 & 2,060 & 0,043 \\
\hline Kecerdasan Emosional & 0,090 & 0,025 & 0,365 & 3,539 & 0,001 \\
\hline Adjusted R Square & & & 0,452 & & \\
\hline FHitung & & & 22,742 & & \\
\hline jignifikansi F & & & 0,000 & & \\
\hline
\end{tabular}

Berdasarkan Tabel 4 dapat disusun persamaan regresi sebagai berikut :

$Y=\alpha+b_{1} X_{1}+b_{2} X_{2}+b_{3} X_{3}+\varepsilon$

$\mathrm{Y}=-8,777+0,128 \mathrm{X}_{1}+0,065 \mathrm{X}_{2}+0,090 \mathrm{X}_{3}+e$

Hasil analisis regresi menunjukkan signifikansi seluruh variabel memiliki nilai kurang dari 0,05 yang berarti bahwa terdapat pengaruh yang signifikan pada seluruh variabel bebas terhadap variabel terikat.

Berdasarkan hasil uji dapat dilihat bahwa nilai dari adjusted $\mathrm{R}^{2}$ (koefisien determinasi) adalah sebesar 0,452 mempunyai arti bahwa sebesar 45,2\% variasi persepsi etis Mahasiswa Akuntansi Fakultas Ekonomi dan Bisnis Universitas Udayana dipengaruhi oleh variasi kecerdasan intelektual, kecerdasan spiritual, dan kecerdasan emosional, sedangkan sisanya sebesar 54,8\% djelaskan oleh faktor lain yang tidak dimasukkan ke dalam model. Nilai F hitung sebesar 22,742 dengan nilai signifikansi $\mathrm{P}$ value 0,000 yang lebih kecil dari $\alpha=0,10$, hal ini menunjukkan bahwa model pada penelitian ini layak untuk digunakan. Berdasarkan hasil penelitian menunjukaan bahwa ketiga variabel independen 
dapat menjelaskan fenomena persepsi etis Mahasiswa Akuntansi Fakultas Ekonomi dan Bisnis Universitas Udayana. Dengan demikian model dapat digunakan dalam penelitian ini atau dapat dinyatakan bahwa model dapat digunakan untuk memproyeksikan karena hasil goodness of fit-nya baik karena nilai $\mathrm{F}$ hitung sebesar 22,742 dan nilai signifikansi $\mathrm{P}$ value 0,000 .

Hasil analisis regresi moderasi dalam penelitian ini adalah sebagai berikut:

Berdasarkan tabel 4 hasil analisis pengaruh kecerdasan intelektual terhadap persepsi etis menunjukkan nilai signifikansi sebesar $0,005<0,1$. Hal tersebut mengandung makna bahwa kecerdasan intelektual berpengaruh positif dan signifikan terhadap persepsi etis Mahasiswa Akuntansi Fakultas Ekonomi dan Bisnis Universitas Udayana.

Berdasarkan tabel 4 hasil analisis pengaruh kecerdasan spiritual terhadap persepsi etis menunjukkan nilai signifikansi sebesar $0,043<0,1$. Hal tersebut mengandung makna bahwa kecerdasan spiritual berpengaruh positif dan signifikan terhadap persepsi etis Mahasiswa Akuntansi Fakultas Ekonomi dan Bisnis Universitas Udayana.

Berdasarkan tabel 4 hasil analisis pengaruh kecerdasan emosional terhadap persepsi etis menunjukkan nilai signifikansi sebesar $0,001<0,1$. Hal tersebut mengandung makna bahwa kecerdasan emosional berpengaruh positif dan signifikan terhadap persepsi etis Mahasiswa Akuntansi Fakultas Ekonomi dan Bisnis Universitas Udayana.

Hipotesis pertama menyatakan bahwa kecerdasan intelektual berpengaruh positif terhadap persepsi etis mahasiswa akuntasi. Hasil penelitian ini sejalan 
dengan teori perkembangan moral yang menyatakan kecerdasan intelektual berpengaruh terhadap persepsi etis. Sehingga semakin baik kecerdasan intelektual yang dimiliki seseorang maka persepsi etis yang dimiliki juga akan semakin baik. Kecerdasan intelektual seseorang yang semakin tinggi akan membangun sebuah persepsi terhadap perilaku etis yang semakin baik, hal ini dikarenakan pola pikir atau cara pandang seseorang terhadap perilaku etis akan semakin baik jika dia dapat mempertimbangkan hal-hal baik yang etis disekitarnya sejalan dengan kecerdasan intelektual yang dimilikinya. Hasil penelitian ini sejalan dengan hasil penelitian yang dilakukan oleh Risela (2016) dan Arshinta dkk., (2017) yang mengungkapkan bahwa kecerdasan intelektual berpengaruh poisitif terhadap persepsi etis.

Hipotesis kedua menyatakan bahwa kecerdasan spiritual berpengaruh positif terhadap persepsi etis mahasiswa akuntasi. Dengan begitu dapat dinyatakan bahwa semakin baik kecerdasan spiritual, maka persepsi etis yang dimiliki juga semakin baik. Kecerdasan spiritual yang tinggi pada seseorang yang salah satunya berupa kepercayaan mengenai hal-hal baik terkait hubungannya dengan Tuhan akan membentuk persepsi etis yang semakin baik karena hal tersebut sejalan dengan definisi dari persepsi etis itu sendiri. Hasil penelitian ini sejalan dengan hasil penelitian yang dilakukan oleh Arshinta dkk., (2017) yang mengungkapkan bahwa kecerdasan spiritual berpengaruh poisitif terhadap persepsi etis.

Hipotesis ketiga menyatakan bahwa kecerdasan emosional berpengaruh positif terhadap persepsi etis mahasiswa akuntasi. Hasil penelitian ini sejalan dengan teori perkembangan moral yang menyatakan kecerdasan emosional 
berpengaruh terhadap persepsi etis. Sehingga semakin baik kecerdasan emosional, maka persepsi etis yang dimiliki juga semakin baik. Salah satu bentuk dari kecerdasan emosional yaitu mampu menahan diri dari sifat emosional itu sendiri akan mempengaruhi pola pikir seseorang sehingga mereka cenderung akan memiliki persepsi etis yang semakin baik. Hasil penelitian ini sejalan dengan hasil penelitian yang dilakukan oleh Arshinta dkk., (2017) yang mengungkapkan bahwa kecerdasan emosional berpengaruh poisitif terhadap persepsi etis.

\section{SIMPULAN}

Berdasarkan hasil analisis dan pembahasan mengenai bagaimana Pengaruh Kecerdasan Intelektual, Kecerdasan Emosional, dan Kecerdasan Spiritual Pemilik terhadap Persepsi Etis Mahasiswa Akuntansi, maka dapat ditarik kesimpulan sebagai berikut. Kecerdasan intelektual memiliki pengaruh positif terhadap persepsi etis mahasiswa akuntansi, hal tersebut mengindikasikan bahwa jika kecerdasan intelektual yang semakin baik akan membuat persepsi etis mahasiswa yang semakin baik pula. Kecerdasan spiritual berpengaruh positif terhadap persepsi etis mahasiswa akuntansi, hal tersebut mengindikasikan bahwa kecerdasan spiritual yang semakin baik akan mambuat persepsi etis mahasiswa akuntansi yang semakin baik pula. Kecerdasan emosional berpengaruh positif terhadap persepsi etis mahasiswa akuntansi, hal ini mengindikasikan bahwa kecerdasan emosional semakin baik akan membuat persepsi etis mahasiswa akuntansi yang semakin baik pula.

Berdasarkan kesimpulan hasil penelitian yang telah dipaparkan di atas, 
peneliti menyarankan kepada pihak kampus untuk meningkatkan pemahaman dalam melihat konsekuensi dari setiap keputusan. Perlu adanya penambahan mata kuliah ataupun waktu khusus mengenai manajemen risiko, dikarenakan pada hasil kuesioner pernyataan "saya selalu melihat konsekuensi dari setiap keputusan yang saya ambil" memiliki skor yang paling rendah dibandingkan dengan pernyataan lainnya. Bagi penelitian selanjutnya diharapkan dapat memperluas ruang lingkup penelitian dengan menggunakan sampel mahasiswa akuntansi dari berbagai program pendidikan tinggi yang ada, serta memperluas angkatan mahasiswa yang dipergunakan sebagai sampel. Selain itu penelitian selanjutnya juga dapat menambahkan beberapa variabel khususnya faktor eksternal yang mempengaruhi persepsi etis mahasiswa akuntansi seperti status sosial ekonomi, muatan etika dalam pengajaran akuntansi dan faktor lainnya yang belum diteliti oleh peneliti.

\section{REFERENSI}

Agustini, \& Herawati. (2010). Pengaruh Kecerdasan Intelektual, Kecerdasan Emosional, dan Kecerdasan Spiritual terhadap Sikap Etis Mahasiswa S1 Akuntansi. E-Jurnal Universitas Pendidikan Ganesha Singaraja.

Anderson, G. M. (1988). Mr. Smith and the Preachers: The Economics of Religion in the Wealth of Nations, Journal of Political Economy, 96(5), 1066-1088.

Aprilianto, R. (2017). Pengaruh Kecerdasan Emosional, Kecerdasan Intelektual, dan Love of Money terhadap Persepsi Mahasiswa mengenai Etika Profesi Akuntan. Jurnal Universitas Diponegoro, 6(2), 1-12.

Aprina, N. S. H., Aida, S. S., dan Intiyas, U. (2018). Sifat Machiavelli, Tekanan Ketataan dalam Ketataan dalam Keputusan Etis: Keputusan Individu dan Kelompok, Jurnal Dinamika Akuntansi dan Bisnis, 1(5), 101-116.

Arshinta, F., Djasuli, M., \& Rinawati, Y. (2017). Faktor-Faktor yang Mempengaruhi Persepsi Etika Mahasiswa Akuntansi dengan Love of Money sebagai Variabel Intervening. Jurnal Keuangan Dan Perbankan, 
2(13), 128-140.

Bariyima, D. K. (2012). Auditor Internaling and Performance of Government Enterprises: A Nigeria Study. Double Blind Peer Reviewed International Research Journal, 12(6), 1-17.

Bertens, K. (2000). Etika Bisnis. Yogyakarta: Penerbit Kanisius.

Biberma, J. and Whittey, M. (1997). A Postmodern Spiritual Future For Work. Journal of Organizational Change Management, 10(2), 30-188.

Christin. (2007). Persepsi Mahasiswa Terhadap Etika Penyusunan Laporan Keuangan. Jurnal Universitas Stikubank.

Emmons, R. A. (2000). Is spirituality intelligence? Motivation, cognition, and the psychology of ultimate concern. Int. J. Psychol. Religion, 10(1), 3-26.

Elias, R. Z. dan Farag, M. (2010). The relationship between accounting students' love of money and their ethical perception. Managerial Auditing Journal, 25(3), 269-281.

Grasmick, H. G., Bursik, R. J. dan Cochran, J. K. (1991). Render Unto Caesar What Is Caesar's: Religiosity and Taxpayers Inclinations to Cheat, Sociological Quarterly, 32(2), 251-266.

Gray, R., Bebbington, J., dan McPhail, K. (1994). Teaching ethics in accounting and the ethics of accounting teaching: Educating for immorality and a possible case for social and environmental accounting education, Accounting Education, 3(1), 51-75.

Goleman, D. (2005). Kecerdasan Emosi untuk Mencapai Puncak Prestasi. Jakarta: PT Gramedia Pustaka Utama.

Idrus, M. (2002). Kecerdasan Spiritual Mahasiswa Yogyakarta, Psikologi Phronesis, Jurnal Ilmiah dan Terapan, 8(4).

Kotler, K. (2014). Manajemen Pemasaran. Jakarta: Erlangga.

Kurniawan, I. dan Widanaputra, A. A. G. P. (2017). Pengaruh Love of Money dan Machiavellian terhadap Persepsi Etis Mahasiswa Akuntansi. E-Jurnal Akuntansi Unud, 3(21), 2253-2281.

Luna-Arocas, R. dan Tang, T. L. P. (2004). The love of money, satisfaction, and the protestant work ethic: Money profiles among university professors in the U.S.A. and Spain, Journal of Business Ethics, 50(4), 329-354.

Mardawati, R. (2014). Pengaruh Orientasi Etis, Gender, dan Pengetahuan Etika terhadap Persepsi Mahasiswa Akuntansi atas Perilaku Tidak Etis 
Akuntan. Jurnal Universitas Negeri Yogyakarta, 20-125.

McGee, R. W. dan Cohn, G. M. (2008). Jewish Perspectives on the Ethics of Tax Evasion, Journal of Legal, Ethical and Regulatory Issues, 11(2), 1-32.

Misbach, I. H. (2008). Antara IQ, EQ, dan SQ. Pelatihan Guru se-Indonesia Jurusan Psikologi Fakultas Ilmu Pendidikan Universitas Pendidikan Indonesia.

Novius, A. (2008). Perbedaan Persepsi Intensitas Moral Mahasiswa Akuntansi dalam Proses Pembuatan Keputusan Moral. Jurnal Universitas Diponegoro, 26-27.

O'Leary, C. dan Cotter, D. (2000). The Ethics of Final Year Accountancy Students: An International Comparison. Managerial Auditing Journal, 15(3), 108-115.

Pemayun, A. A. G. A. (2018). Pengaruh Religiusitas, Status Sosial Ekonomi dan Love of Money Pada Persepsi Etis Mahasiswa Akuntansi Fakultas Ekonomi dan Bisnis Universitas Udayana. Jurnal Akuntansi Universitas Udayana, 23(2), 1600-1628.

Purnamaningsih, N. K. A. dan Ariyanto, D. (2016). Pengaruh Gender, Usia, Tingkat Pendidikan, dan Status Sosial Ekonomi terhadap Persepsi Etis Mahasiswa Akuntansi. E-Jurnal Akuntansi Universitas Udayana, 2(17), $996-1029$.

Risela, D. A. (2016). Pengaruh Kecerdasan Intelektual, Kecerdasan Emosional dan Kecerdasan Spiritual terhadap Persepsi Etis Mahasiswa Akuntansi Kreatif di Perusahaan. Jurnal Akuntansi Universitas Negeri Yogyakarta, $6(1)$.

Wardana, A. A. G. A., \& Mimba, N. P. S. H. (2016). Pengaruh Kecerdasan Intelektual, Kecerdasan Emosional, Kecerdasan Spiritual, dan Gender pada Sikap Etis Mahasiswa Magister Akuntansi Universitas Udayana. EJurnal Fakultas Ekonomi Dan Bisnis Universitas Udayana, 7(2), 390399.

Wati, M., \& Sudibyo, B. (2016). Pengaruh Pendidikan Etika Bisnis dan Religiusitas terhadap Persepsi Etis Mahasiswa Akuntansi. Jurnal Economica, 2(12).

Widyaningrum, A. (2014). Determinan Persepsi Etis Mahasiswa Akuntansi dengan Love of Money sebagai Variabel Intervening. Jurnal Fakultas Ekonomi Dan Bisnis Universitas Brawijaya, 1-28. 
Chandra Wijaya dan Maria Madiatrix Ratna Sari. Pengaruh ...

Zohar, \& Marshall. (2005). Spiritual Capital. Bandung: Mizan. 